\title{
SH9 - Sistemas de Información Geográfica como herramienta de monitoreo de coberturas para estudios de cambio climático
}

\author{
Aguilar-Arias, Heileen* \\ Programa de Investigaciones Aerotransportadas, Centro Nacional de Alta Tecnología \\ (PRIAS-CENAT) \\ Universidad Estatal a Distancia de Costa Rica
}

\section{Resumen}

T os sistemas de información geográfica (SIG) son una matriz de componentes que participan en el proceso de datos y producción de información. Actualmente son empleados por organizaciones como herramienta clave para la toma de decisiones. En este sentido, Costa Rica ha asumido el reto desde 2007 de ser carbono neutral para el 2021, con lo cual se han adquirido fuertes compromisos vinculados con la estrategia de reducción de emisiones por deforestación y degradación (REDD+) para la mitigación del cambio climático. Por lo tanto, es necesario contar con herramientas que permitan identificar y definir las fuentes o sumideros de carbono; así mismo, desarrollar estrategias para un manejo sostenible y un ordenamiento territorial que permita identificar el avance de la frontera agropecuaria y cambios en la cobertura/uso del suelo que generen presión directa sobre la cobertura forestal. El objetivo de este artículo es mostrar la aplicabilidad de los SIG como herramienta de monitoreo de cultivos y complemento a la toma de decisiones para la estrategia de cambio climático. Para ello, se expone un flujograma de trabajo para el procesamiento de datos geoespaciales con imágenes Landsat adquiridas para el 2016, enfocado el estudio en tres regiones de Costa Rica: Región Huetar Norte (RHN), Región Huetar Caribe (RHC) y Región Brunca (RB) para determinar el porcentaje de ocupación de la tierra con paisajes productivos de piña en las tres regiones de estudio. Los resultados muestran un total de 37718 hectáreas de piña para la RHN, 8030 hectáreas en RB y 11578 hectáreas en RHC.

Palabras clave: Costa Rica, piña, cambio climático, REDD+, imágenes satélites, Landsat

\section{Abstract}

$\mathrm{G}^{\mathrm{s}}$ eographic information systems (GIS) is a matrix of components involved in data processing and information production. Currently they are employed by organizations as a key tool for making decision. Costa Rica has taken on the challenge since 2007 to be carbon neutral by 2021, which have been acquired strong commitments linked to the strategy of reducing emissions from deforestation and degradation (REDD + ) for mitigation of climate change. Therefore, it is necessary to have tools to identify and define the sources or carbon sinks; likewise, develop strategies for sustainable management and land use planning to identify the advance of the agricultural frontier and changes in land cover that generate direct pressure on forest cover. The main objective of this article is to show the applicability of GIS as a tool for monitoring crops and supplement the decision making for climate change strategy. For this, a workflow diagram for processing geospatial data with Landsat images acquired for 2016 is exposed, focused the study in three regions of Costa Rica: Huetar Norte (RHN), Huetar Caribbean (RHC) Region Brunca (RB) to determine the percentage of occupation of land for productive landscapes pineapple in the three study regions. The results show a total of 37718 hectares of pineapple for RHN, RB 8030 hectares and 11578 hectares in RHC.

Keywords: Costa Rica, pineapple, climate change, REDD +, satellite images, Landsat. 